\title{
Developing E-Brochure Project -Based Learning Materials for English Creative Writing
}

\author{
Difiani Apriyanti ${ }^{1}$, Sumira ${ }^{2}$, Witri Handayani ${ }^{3}$ \\ \{difi.apriyanti@gmail.com ${ }^{1}$, sumiradoano@gmail.com ${ }^{2}$ wietripnp@gmail.com ${ }^{3}$ \} \\ Kampus Politeknik Negeri Padang Limau Manis Padang ${ }^{123}$
}

\begin{abstract}
This study is a R\&D of E-Brochure Project. It is a supplementary material for Engineering students of PNP who are learning General English. This material was developed based on Gall and Borg Small Scale model that consists of needs analysis, planning objectives, developing preliminary forms of product, preliminary field testing, main product revision, and main field testing. Meanwhile, this article only discusses the main fied testing. The approach used was the combination of Task Based Learning (TBL) and Project Based Learning (PBL). Therefore, three students were taken as the samples. After implementing EBrochure Project in the learning process, the students come out of three brochures with different themes which were science, religion, and tourism. The brochures were then being assessed in order to find out the quality of their writing task performance. The data was analyzed quantitatively and qualitatively. The result of the analysis is the students' writing content are more variative. Details are given in the expression which make the description vivid and intersting. Thus it can be concluded that E-Brochure Project is effective in improving students‘ English writing skill.
\end{abstract}

Keywords: Material, Brochure, Writing.

\section{Introduction}

In Indonesia, English is a foreign language. It is not used as the second language or instructional language in schools and universities. Fortunately, Higher Institutions always provide English in the curriculum. It can be seen that at least in one of the whole semester, there will be an English subject. Usually, it is named as General English. The institutions realize that the students will face a competitive world, and seeking a job will be challenging. By only bringing certificate of degree is not enough, therefore the students are equipped with English skills-active and passive. Furthermore, competences in communication between university training and market demand are critical [1].

It cannot be denied that teachers are still facing difficulties in teaching English in Higher Institution although the students have learned English previously in High Schools. The students are not only lack in the knowledge and skills, but also in motivation. Meanwhile attitude is the most crucial factors for learning a foreign language [2]. Therefore, the teachers must be creative and innovative in choosing and using the right learning material. Although market provides many of them, but the one that meets the students' needs is hard to be found. The best one will be the learning material that is created or modified by the teachers who are teaching the class.

In teaching English, the teacher must give students materials that are challenging and in the same time interesting. While the teacher is functioned as a guidance that controls the students to be on the right track. Although in this era, internet is mostly used as learning material aid since 
it can give authentic pictures of many things, but the best is still the one is material that put the students on an experience where they can see, hear, smell, and feel it. Actually, there are several studies have been conducted related to learning material development for ELT. There is learning material which is developed for ELT in general such as Developing Engish Language Teaching Materials Using Text-driven Approach [3], or more specific English skills such as developed learning material for English speaking [4], developed learning material for English public speaking [5], and developed learning material for English writing using Accelerated Learning Approac [6]

Politeknik Negeri Padang (PNP) is an higher institution that has equipped the students with English. The Engineering Departments of PNP provides English in different length of time. All the Engineering Departments students are equipped with English subject, although the length of time for studying this subject is different from one to another. One thing which is the same is for the early semester of learning English, the students are learning General English, and in the following semester, the students are learning English for Specific Purpose (ESP). In teaching General English in Engineering Departments, all the teachers are using a module which is compilation of the four skills- listening, speaking, reading, and writing. Mostly the tasks are integrated skils, and in the same time building their motivation. This situation was also found in Engineering university students in Saudi Arabia where they suggest negative attitude on learning English [2] .

Most of the tasks given to the students will end by performing a writing like writing report, writing letter, writing application letter, and many other more. From the pre-interview to the English teachers, the students need more time to start writing. It can even be more than half an hour for them to be in front of their blank paper. While from pre interview to the students, they admit that they usually lost ideas or felt blank every time they have to start writing. Although the class have talked or did brainstorming as the lead in or warming up, and moreover the teachers have provided aid such as internet to get vivid picture of what will be talked about, but the students were still facing the problem in pouring their ideas in a piece of paper.

Therefore a supplementary material was developed by using the combination of Task Based Learning (TBL) and Project Based Learning (PBL). TBL is an approach to the teaching of language in which tasks of one kind or the other are seen as essential activities for language learning [7]. While in PBL, studdent ${ }^{\star}$ self-reliant and critical thinking will improve [8]. The supplementary material is named Digital Brochure Project. In this main field testing step, DBP was used in the learning process to three students in order to see e the effectivenes of it in improving students' writing task.

\section{Method}

Educational Research and Development (R\&D) is an industry- based development model in which new product is designed [9]. The steps in this model are needs analysis, planning objectives, developing preliminary forms of product, preliminary field testing, main product revision, and main field testing. It is usually called as Gall and Borg Small Scale Model. This article only discusses the main fied testing. In this step, three students were taken as the sample. After implementing E-Brochure Project in the learning process, the students come out of three brochures with different themes which were science, religion, and tourism. The brochures were then being assessed in order to find out the quality of their writing task performance. The data was analyzed quantitatively and qualitatively. 


\section{Results and Discussion}

The three brochures were done being analyzed using the rubric. The results were as followed:

\begin{tabular}{|l|l|l|l|l|}
\hline & Excellent & Good & Satisfactory & Needs Improvement \\
\hline Organization of Information Presented & & v (12) & & \\
\hline Content -Accuracy and Information Validity & $\mathrm{v}(15)$ & & & \\
\hline Spelling and Mechanics & & $\mathrm{v}(12)$ & & \\
\hline Attractiveness \& Organization & $\mathrm{v}(15)$ & & & \\
\hline Graphic/Pictures & $\mathrm{v}(15)$ & & & \\
\hline TOTAL: 69 & & & & \\
\hline
\end{tabular}

Figure 1. The Assessing of The first Brochure

\begin{tabular}{|l|c|c|c|c|}
\hline & Excellent & Good & Satisfactory & Needs Improvement \\
\hline Organization of Information Presented & $\mathrm{v}(13)$ & & & \\
\hline Content -Accuracy and Information Validity & $\mathrm{v}(15)$ & & & \\
\hline Spelling and Mechanics & & $\mathrm{v}(12)$ & & \\
\hline Attractiveness \& Organization & & $\mathrm{v}(11)$ & & \\
\hline Graphic/Pictures & $\mathrm{v}(14)$ & & & \\
\hline TOTAL: 65 & & & & \\
\hline
\end{tabular}

Figure 2. The Assessing of the Second Brochure

\begin{tabular}{|l|c|l|l|l|}
\hline & Excellent & Good & Satisfactory & Needs Improvement \\
\hline Organization of Information Presented & v (13) & & & \\
\hline Content -Accuracy and Information Validity & v (14) & & & \\
\hline Spelling and Mechanics & v (14) & & & \\
\hline Attractiveness \& Organization & v (15) & & & \\
\hline Graphic/Pictures & v (15) & & & \\
\hline TOTAL: 71 & & & & \\
\hline
\end{tabular}

Figure 3. The Assessing of the Third Brochure 
From the assessing scoring in the three table above, it is identified that the mean of the achievement is : $69+65+71: 3=68$. With the category in figure 4 , it is seen that the students' writing is in the level excellent. Therefore, DBP can improve students' writing skill.

\begin{tabular}{|c|l|}
\hline Range of Score & \multicolumn{1}{c|}{ Criterion } \\
\hline $65-75$ & The Writing is Excellent \\
\hline $50-60$ & The Writing is Very Good \\
\hline $30-45$ & The Writing is Good \\
\hline $5-25$ & The Writing is Poor \\
\hline
\end{tabular}

Figure 4.Criterion of Writing

Digital Brochure Project (DBP) has made the students write clearly in the beginning, middle, and end of the brochure content. DBP made the students able to tell the facts precisely with what their experiencing in. Things that they see, feel, hear, and smell can be accurately poured into the writing by giving details. In the three brochures, although there were still few mistakes in the spelling, the brochures were written in attractive way where the readers can get a vivid pictures of the facts and can change their thought and feeling. The readers can feel that they are brought to a story which is in a good flow. The graphic is also excellent and attractive. It goes well with the text. Pictures were chosen selectively and the colour also gives a different sense when the readers hold the brochures.

The results really show that although advanced the technology exists around us, but if it does not give real experience to the person, it means nothing. As it is said that the focal learning, giving life, texture, and subjective personal meaning to abstract concepts and at the same time providing a concrete, publicly shared references point for testing, the implications and validity ideas created during the learning process comes from personal experience [10].

Furthermore, language teachers' responsibility has risen, therefore they must improve themselves [11]. They must be able to be creative and innovative to the recent changes happened in education system. They must not be trapped with technology that arouse. They have to be aware that the process of learning in the class is still in their hands.

\section{Conclusion}

It can be concluded the learning material development is needed to be conducted especially by the the teacher who are teaching the classroom. For General English class in Engineering Department of Politeknik Negeri Padang, it is possible nowdays to ask the students step out their comfort zone, by conducting a project outside their campus. The students must be given a task which motivate them in the same time built their critical thinking. DBP is one of the material that offer it. The English teachers act as a person who have to make sure that the students are on the right track.The strengths and the weaknesses of the students are required tobe identified by the teachers in order to develop English skills to the right decision[12].

\section{References}


[1] Á. R. López, J. E. Souto, and M. L. A. Noblejas, "Improving teaching capacity to increase student achievement: The key role of communication competences in Higher Education," Stud. Educ. Eval., vol. 60, no. October, pp. 205-213, 2019.

[2] M. A. Alqahtani, "Teaching English for specific purposes: Attitudes among saudi engineering students," English Lang. Teach., vol. 8, no. 7, pp. 76-94, 2015.

[3] H. Park, "Developing English Language Teaching Materials Using a Text-driven Approach," in MATSDA conference, 2013.

[4] P. Kusumawati, "Developing English Learning Material for Speaking Skill," Premise J., vol. 1, 2017.

[5] M. Z. A. Hakim, Mar, and Jafre, "Developing public speaking materials based on communicative language teaching for EFL learners in Indonesia," 2018, no. June.

[6] D. Santoso, "Developing academic writing materials for learners of English education department based on accelerated learning approach," Pertanika J. Soc. Sci. Humanit., vol. 27, no. 2, pp. 863-875, 2019.

[7] M. Bygate, "Sources , developments and directions of task-based language teaching," no. May, pp. 37-41, 2015.

[8] N. Dimmitt, "the Power of Project Based Learning: Experiential Education To Develop Critical Thinking Skills for University Students," in CBU International Conference Proceedings, 2017, vol. 5, no. 1, pp. 575-579.

[9] D. M. Gall, P. J. Gall, and R. W. Borg, Educational Research, 7th ed. Allyn \& Bacon, 2003.

[10] D. A. Kolb, Experiential Learning: Experience as The Source of Learning and Development, no. 1984. Prentice_Hall, 1984.

[11] N. Abal1, "English Language Teachers' use of, Competence in and Professional Development needs for Specific Classroom Activities," Procedia - Soc. Behav. Sci., vol. 70, pp. 181-187, 2013.

[12] K. Poolsawad, S. Kanjanawasee, and J. Wudthayagorn, "Development of an English Communicative Competence Diagnostic Approach,” Procedia - Soc. Behav. Sci., vol. 191, pp. 759-763, 2015. 